This article was downloaded by: [J oseph Harris]

On: 06 October 2011, At: 15:36

Publisher: Routledge

Informa Ltd Registered in England and Wales Registered Number: 1072954 Registered

office: Mortimer House, 37-41 Mortimer Street, London W1T 3J H, UK

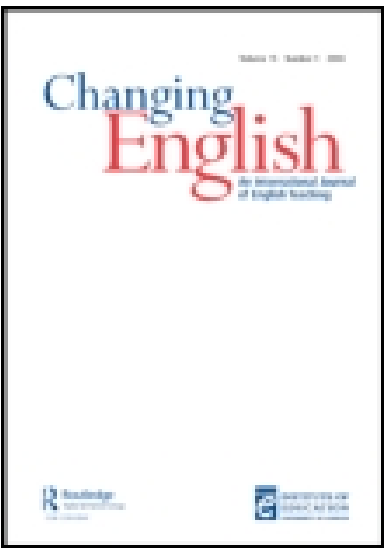

\title{
Changing English
}

Publication details, including instructions for authors and subscription information:

http:// www.tandfonline.com/loi/ ccen20

\section{Identity Matters: Schooling the Student Body in Academic Discourse}

\author{
J oseph Harris ${ }^{a}$ \\ a Department of English, Duke University, Durham, North Carolina, \\ USA
}

Available online: 20 Sep 2011

To cite this article: J oseph Harris (2011): Identity Matters: Schooling the Student Body in Academic Discourse, Changing English, 18:3, 331-333

To link to this article: http:// dx.doi.org/ 10.1080/ 1358684X.2011.602843

\section{PLEASE SCROLL DOWN FOR ARTICLE}

Full terms and conditions of use: http://www.tandfonline.com/page/terms-andconditions

This article may be used for research, teaching, and private study purposes. Any substantial or systematic reproduction, redistribution, reselling, loan, sub-licensing, systematic supply, or distribution in any form to anyone is expressly forbidden.

The publisher does not give any warranty express or implied or make any representation that the contents will be complete or accurate or up to date. The accuracy of any instructions, formulae, and drug doses should be independently verified with primary sources. The publisher shall not be liable for any loss, actions, claims, proceedings, demand, or costs or damages whatsoever or howsoever caused arising directly or indirectly in connection with or arising out of the use of this material. 


\section{BOOK REVIEW}

Identity Matters: Schooling the Student Body in Academic Discourse, by Donna LeCourt, Albany, State University of New York Press, 2004, 245 pp., US\$29.95 (paperback), ISBN 109780791460566

What are writing teachers to do when faced with difference? Do we try to help students acquire the distinctive idioms of academic discourse, to write as we do? Or do we respect their home languages and resist asking them to assimilate? Donna LeCourt notes that, when she first began work on Identity Matters, she planned to argue for a familiar middle position in this debate, one that urges teachers to help students draw on the 'multiple voices' - of home, work, community, school - that they all already possess in learning how to write for the academy (190). Instead her book turned into an exploration of why such a hybrid style proves so hard to teach and learn.

LeCourt grounds her study in a reading of 46 'literacy autobiographies' - about half of which are written by undergraduate 'basic writers' and the other half written by graduate students in English at 'a large midwestern university' in the US (9). She reasons that both groups are faced with acquiring a new discourse - either of 'academic writing' or of 'English studies' - and thus that they have much to tell us about what it might mean to forge a new identity as a writer. That seems fair enough, although I wish that LeCourt had spent more time setting up the context of her study. We never find out, for instance, exactly what a 'literacy autobiography' is, or what sort of assignments students wrote them in response to, or how one is placed as a 'basic writer' at Midwestern U, or what kinds of careers the English grad students there imagine themselves as training for. Rather, we must glean what we can of these writers through her brief quotations of their prose.

And that prose turns out to be suggestive and compelling. Both the basic writers and grad students write eloquently about their past experiences and current struggles with writing. Many express high levels of anxiety about the writing tasks they are now being asked to take on. Few seem to feel they can build on their past successes with writing to succeed in that work - a worry which seems to belie the notion that academic writing allows for a blending of diverse voices.

LeCourt argues, to the contrary, that academic writing is neither multivocal nor 'transparent', but rather reflects the values of the dominant culture. She identifies two different problems faced by student writers who are not male or white or middle class but who must still try to master this discourse. On the one hand, there are writers, usually African Americans, who do indeed retain two voices, but who feel they must keep their 'home' and 'academic' identities separate. On the other hand, there are writers, often from the working class, who abandon their home discourses in order to assume the language of the academy. The choice is to compartmentalize or to pass. Either results in anxiety. 
LeCourt re-enacts this problem in the structure of her book. Most of Identity Matters is written in echt academese - with lengthy and abstruse summaries of the identity theories of Michel Foucault and Stuart Hall. But LeCourt also interrupts this main text with a series of brief autobiographical interchapters, written in a much more intimate tone, recounting her own hopes, as a working-class girl, of gaining a new life through going to college - and then of her own sense of loss once that transformation occurred. But the moments I find most compelling in Identity Matters are neither theoretical nor personal. Rather, they occur when LeCourt quotes the basic writers and grad students in her study at length. In this still too rare move, she both honours the intelligence and ambition of these newcomers to the academy, and suggests that scholars of literacy have much to learn from paying close attention to the work of developing or apprentice writers.

There is an interesting tension in both sets of student writings. LeCourt focuses on the content of what her subjects have to say, the themes they return to - which, time after time, are loss, assimilation, struggle, and alienation. But I am struck by the quality of the prose she quotes - its analytic, self-reflexive quality. For instance, here is a basic writer from her study:

I have since come to realize that no matter how high I build my knowledge tower it cannot stand without a strong base. This base is what I get from the communities I started in. This my literacy base, is something I work to stay in touch with. In order to stay in touch I will sometimes talk as I used to and not as I do now. (164)

What more could you ask from a writer? This passage may express a reasonably cautious attitude towards academic discourse, but at the same time it enacts the core values of intellectual writing - a sensitivity to language (the metaphor of 'tower' and 'base') and a tolerance of ambiguity ('I will sometimes talk as I used to and not as I do now'). Indeed, I'd argue that a generous and sceptical attitude is precisely what we want to teach in the name of intellectual writing. And by those standards, almost everyone that LeCourt quotes in Identity Matters is already a pretty good intellectual writer.

I suspect that I came to the academy from a similar route as LeCourt. I empathize with the sense of loss that she describes in moving from a working-class community to an academic milieu. But I would also want to emphasize a gain. I believe my training as an academic has helped me become more thoughtful and introspective. LeCourt begins her book by talking about two students who, in effect, refused her invitation to enter the academic community. One was a young Mormon woman; the other was a white, upper-middle-class male. Both were strong academic writers, but both also felt that learning critical discourse threatened who they wanted to become in their lives. LeCourt worries about what minority and working-class students might lose when they learn how to write academic discourse. I think those two students lost far more when they decided not to.

But there is a loss to the academy, too, when we fail to listen to the voices of writers who don't always quite sound like us. What I most admire about Identity Matters is LeCourt's willingness to learn from the developing writers she studied.

\section{Notes on contributor}

Joseph Harris is an associate professor of English at Duke University, where he teaches academic writing, critical reading, creative nonfiction, and digital writing. He is the author 
of A Teaching Subject: Composition Since 1966 (Prentice Hall, 1997), and Rewriting: How to Do Things with Texts (Utah State University Press, 2006), and co-editor of Teaching with Student Texts: Essays Toward an Informed Practice (Utah State University Press, 2010).

Joseph Harris Department of English Duke University Durham, North Carolina, USA (C) 2011, Joseph Harris DOI: $10.1080 / 1358684 X .2011 .602843$ 